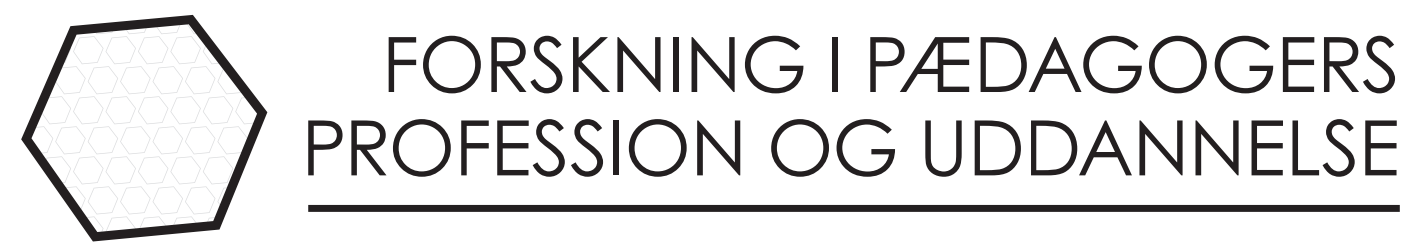

\title{
Klubpaedagogen mellem demokrati, frihed og markedsgørelse?
}

- Tre nøglefortcellinger om klubpcedagogisk professionsidentitet

\section{Lea Ringskou}

Lektor, Pædagoguddannelsen VIA, Campus Viborg lri@via.dk

\section{Christoffer Vengsgaard}

Forhenværende lektor, Pædagoguddannelsen VIA, Campus Viborg chrikve@aarhus.dk

\section{Caroline Bach}

Lektor, Pædagoguddannelsen VIA, Campus Horsens caba@via.dk 
Resumé

Artiklen omhandler et toårigt forskningsprojekt på VIA Pædagoguddannelse om klubpædagogisk professionsidentitet. I forskningsprojektet er der udført 11 kvalitative semistrukturerede interviews. Ud fra interviewene konstruerer vi analytisk tre dominerende narrativer: klubpædagogen som demokratisk medborgerskaber, frihedens klubpædagog og klubpædagogen som sælger. Ud fra narrativerne præsenterer vi tre større historisk og kulturelt forankrede nøglefortællinger om klubpædagogisk professionsidentitet. De to første narrativer indeholder nøglefortællinger om demokrati og frihed, der trækker på klassisk reformpædagogik og kritisk frigørende pædagogik. Heroverfor indeholder narrativet pædagogen som sælger en historisk nyere nøglefortælling om markedsgørelse. Vi betragter mødet mellem nøglefortællingerne som en mere overordnet fortælling om klubpædagogisk professionsidentitet mellem tradition og forandring. Afslutningsvis diskuterer vi, hvilke udfordringer og muligheder mødet mellem nøglefortællingerne, nærmere bestemt mødet mellem demokrati og frihed på den ene side og markedsgørelse på den anden, potentielt kan indeholde i forhold til klubpædagogisk professionsidentitet og omverdenens anerkendelse. På den ene side kan markedsgørelsen tolkes som risiko for dekonstruktion af klubpædagogisk professionsidentitet, der vil kunne udhule nøglefortællingerne om demokrati og frihed. På den anden side kan der argumenteres for, at netop nøglefortællingen om markedsgørelsen kan tolkes som mulighed for at styrke de to andre nøglefortællinger og at den sigt vil kunne bidrage til stabilisering og anerkendelse af klubpædagogisk professionsidentitet.

\section{Abstract \\ Leisure time pedagogue working in youth clubs: between democracy, freedom and marketing? Three key narratives in professional identity of leisure time pedagogues working in youth clubs}

In this article, we present the results of a research project about the professional identity of leisure time pedagogue working in different forms of youth clubs with children and teenagers from 10 to $18+$ years of age. We base the analysis on 11 qualitative semi-structured interviews. Through the analysis, we construct three key narratives: a key narrative concerning democracy, a key narrative concerning freedom and a key narrative concerning marketing (sale). We use these three key narratives to illustrate the complexity of the professional identity of the leisure time pedagogue. Both tradition and renewal characterizes the professional identity of the leisure time pedagogues. In the final section, we discuss the encounter between the key narratives of democracy and freedom on the one hand and the key narrative of marketing on the other. What are the possible pitfalls and potentials in this encounter, when the pedagogues strives for the acknowledgement and acceptance of professional identity? 
Nøgleord

Klubpædagogisk professionsidentitet, klubpædagoger, klub, narrativer, nøglefortællinger

Keywords

Professional identity, leisure time pedagogues, youth club, narratives, key narratives

\section{Indledning}

Klubområdet for de 10 til 18+ årige har gennemgået en række forandringer de sidste 20 år. Eksempelvis bevirkede kommunalreformen i 2007 strukturændringer på området, ligesom folkeskolereformen medførte ændringer i form af reduceret klubtid på grund af længere skoledage og for nogle klubbers vedkommende et øget antal opgaver i skolen (EVA, 2018; Bayer \& Jørgensen, 2016). Klubtilbuddene er forskelligartede, hvilket kommer til udtryk i lovgivningen, hvor de kan fungere efter ikke mindre end fire forskellige lovgivninger: Dagtilbudsloven, Ungdomsskoleloven, Folkeskoleloven og Folkeoplysningsloven (Mikkelsen, Hansen, \& Munkholm, 2017). Forskelligheden ses desuden i kommunernes varierende tilgange til og brug af klubtilbuddene. Nogle kommuner har fastholdt relativt mange klubber i hver bydel, mens andre har slået en række mindre klubber sammen. Nogle kommuner har fastholdt klubber på egne matrikler, mens andre har prioriteret en større sammentænkning og matrikelsammenlægning af klub og skole. Endelig har nogle kommuner valgt at nedlægge klubområdet, som det så ud før kommunalreformen i 2007 og skolereformen i 2014, og gentænke området markant.

Jesper Larsen, tidligere udviklingskonsulent i Ungdomsringen, har foretaget diskurs- og aktantanalyser på klubområdet (Larsen, 2015). Med afsæt i blandt andet fritidspædagogiske policydokumenter analyserer Larsen klubområdet i historisk, ledelsesmæssigt og strategisk perspektiv (Larsen 2015). Desuden kan nævnes antologien "Er du på tværs - Om at lede og krydse grænser i nye pædagogiske landskaber" (Larsen (red.), 2018), hvor Ungdomsringen, herunder Larsen, sammen med forskere fra CBS og DPU, præsenterer analyser af pædagogisk strategisk klubledelse efter skolereformen. Endelig har blandt andet Danmarks Evalueringsinstitut og BUPL udgivet forskningsrapporter om, hvordan og hvor meget klubpædagogerne indgår i skoletiden, hvor mange børn og unge, der går i klub, og hvorfor de vælger klub (EVA 2018; Bayer \& Jørgensen, 2016).

Undersøgelserne giver forskellig viden om klubområdet, hvad angår områdets historik, ledelse, børne- og ungeperspektiver på klublivet og ikke mindst klubberne efter skolereformen i 2014. Imidlertid mangler der forskning, blandt andet forskning specifikt om klubpædagogerne og deres professionsidentitet (Gravesen \& Ringskou 2019 og 2020). Munksgaard, Schmidt og Skovgaard henviser til 
forskningsprojekter om professionsidentitet, hvori der argumenteres for "[...] at pædagogers opfattelse af egen professionsidentitet har betydning for deres professionelle praksis" (2019, s. 69). Manglende forskning om klubpædagogerne kan udfordre såvel uddannelse som praksis (Gravesen \& Ringskou, 2019 og 2020). Intentionen med denne artikel er for det første at bidrage til styrkelse af pædagoguddannelsens vidensgrundlag og til den studerendes dannelsesproces og professionsidentitet som kommende klubpædagog. For det andet kan artiklen være med til at styrke grundlaget for nuværende klubpædagoger, eksplicitere deres klubpædagogiske professionsidentitet og øge omverdenens kendskab til og anerkendelse af klubområdet. Endelig inviterer vi afslutningsvist til videre diskussion og debat om klubberne, nu og i fremtiden.

\section{Teori om (professions)identitet}

I artiklen er vi for det første inspirerede af professor Steen Wackerhausens professionsidentitetsanalyse. I udgangspunktet definerer Wackerhausen professionsidentitet som "[...] de interne forhold etc. hos den enkelte praktiker, der aktivt er med til at 'drive', strukturere, formgive, stabilisere praktikerens praksis", og han understreger, at det er "[...]mangfoldige sam- og modspillende aktører, som tilsammen danner, indvirker på og stabiliserer professionsidentiteten på såvel det konkrete som det institutionelle plan.” (Wackerhausen, 2004, s. 14, 17).

Et væsentligt element i den socialt konstruerede professionsidentitet er Wackerhausens begreb om "nøglefortællinger" (2004, s. 20-21). Nøglefortællinger er større kulturelle, historisk forankrede fortællinger. Fortællingerne kan enten afskrække eller motivere til konkrete praksishandlinger. Afskrækkende nøglefortællinger indeholder ofte en morale om, hvordan tidligere udøvere på feltet har handlet forkert. Motiverende nøglefortællinger indeholder i stedet forbilledlige praksishistorier, hvor handlingen styrkede praksis. Begge former for nøglefortællinger har "en socialiserende effekt på lytteren og en stabiliserende funktion for den fælles professionsidentitet" (Wackerhausen, 2004, s. 21).

Wackerhausens analyse af professionsidentitet og nøglefortællinger rummer en teoretisk pointe om (professions)identitet som social, kulturel konstruktion. En pointe, som blandt andet antropolog Laura Gilliam (2017) og sociolog Richard Jenkins (2004) fremfører i deres teorier om identitet. I dette perspektiv betragtes (professions)identitet som noget, der bliver konstrueret gennem kulturelle kategorier og narrativer i interaktioner - narrativer "[...] som over tid er etableret som meningsfulde, tilskrevet betydninger og har fået en objektiv karakter i de fællesskaber, vi indgår i.” (Gilliam, 2017, s. 123). Nøglefortællinger kan betragtes som væsentlige elementer i professionsidentiteten, hvor de kommer til udtryk eller kan konstrueres gennem en række dynamiske narrativer skabt i interaktion. Narrativer, der ifølge den amerikanske professor i filosofi, Jean Clandinin, indeholder eller bygger på stories to live by, forstået som narrativ viden. En narrativ viden, der i større eller mindre grad bliver retningsgivende for praksishandlinger: "I et 
narrativt perspektiv kan en sådan retningsgivende viden ikke afskrives som ren subjektivisme eller som mystiske egenskaber ved personen. Den må snarere ses som intersubjektiv, social og kulturelt overleveret" (Togsverd, Rothuizen, Jørgensen, \& Weise , 2017, s. 73). Stories to live by er med andre ord ikke blot flygtig viden, skabt af de enkelte klubpædagoger, men derimod rodfæstet i kulturelt overleverede pædagogiske narrativer (nøglefortællinger).

Opsummerende er artiklen baseret på en teoretisk forståelse af klubpædagogers professionsidentitet som en socialt konstrueret størrelse. En størrelse, der bygger på en række nøglefortællinger, som udtrykkes gennem en række narrativer indeholdende narrativ viden, stories to live by. Ud fra disse teoretiske perspektiver er det i forskningsprojektet derfor relevant at undersøge narrativer og nøglefortællinger for at kunne skabe viden om professionsidentiteten.

Endelig er vi inspirerede af Michael Whites (diskursteoretiske narrative terapeut) analyse af (professions)identitetsfordring (White, 2008). White beskriver identitetsfordringen som en treleddet positioneringsproces. I første omgang skal medlemmerne på et givent professionsfelt have konstrueret en intern selvfortælling og identitetskonklusion om, hvem de som professionsgruppe er. Dernæst skal medlemmerne af professionsgruppen positionere sig over for omverdenen ud fra deres selvfortælling (identitetskonklusion). Endelig er det tredje led i identitetsfordringen, at omverdenen forholder sig til den fremsatte identitetskonklusion. Omverdenen kan enten tildele eller ikke tildele identitetskonklusionen sandhedsstatus og dermed enten anerkende eller underkende den. Whites teori om identitetsfordring sættes i spil, når vi afslutningsvist perspektiverende spørger til hvilke potentialer og udfordringer, der kan være forbundet med mødet mellem de fremanalysererede nøglefortællinger i professionsidentiteten, når klubpædagogerne skal positionere sig og have deres identitetskonklusion anerkendt af omverdenen (White, 2008).

\section{Metode og analysestrategi}

Det foreløbige indblik i klubområdet, sat sammen med forskningsprojektets teoretiske tilgang til professionsidentitet, resulterer i følgende forskningsspørgsmål: Hvilke historiske og kulturelt forankrede nøglefortællinger om klubpædagogisk professionsidentitet kan fremanalyseres gennem en undersøgelse og konstruktion af klubpædagogiske narrativer og narrativ viden?

Forskningsprojektets empiri består af 11 kvalitative semistrukturerede interviews med klubpædagoger og klubledere i tre kommuner (kommune a, b og c). De tre kommuner er udvalgt med blik for og ønske om at vedstå klubområdets forskellighed. De tre kommuner adskiller sig fra hinanden ved at operere ud fra forskelligt lovgrundlag og være forskelligt organiserede i praksis. De 11 informanter blev rekrutteret på frivillig basis gennem mundtlig og skriftlig præsentation af forskningsprojektet. Som det vil fremgå af artiklens analyse, udførte langt de fleste af informanterne planlagte og spontane aktiviteter med målgruppen 
(gaming, ture ud af klubben, kreative aktiviteter med mere), havde spontane og planlagte samtaler med målgruppen, tværprofessionelt og -sektionelt samarbejde med videre. Blandt klublederne arbejdede en del af disse i halvtidslederstillinger, mens andre var ledere på fuld tid. Halvtidslederstillinger indgik i klubbernes normering og halvtidslederne varetog forskelligartede pædagogiske opgaver i klubdelen på lige fod med klubpædagogerne. Hvad angår målgruppen, var rekrutteringsgrundlaget i alle tre kommuner relativt blandet, med deltagelse af børn og unge fra forskellig socioøkonomisk baggrund, dog med tendens til svag overvægt af børn i udsatte socioøkonomiske positioner.

Forud for interviewene udarbejdede vi et script i form af en løst struktureret interviewguide. Interviewguiden blev brugt som en fleksibel huskeliste med relevante tematikker konstrueret ud fra forskningsspørgsmålet samt forslag til åbne spørgsmål under hver tematik (Kvale \& Brinkmann, 2015, s. 77-97). ${ }^{1}$ I konstruktionen af interviewguiden og tematikkerne tog vi afsæt i vores kendskab til og teoretiske forforståelse fra eksisterende viden på klubområdet med blik for eksempelvis klubpædagogernes arbejde og møde med selve målgruppen og deres tværprofessionelle og tværsektorielle samarbejdsrelationer (Larsen, 2015; Larsen (red), 2018; Bayer \& Jørgensen, 2016; EVA, 2018). Den relativt åbne interviewguide gjorde det muligt at udforske og fastholde det narrative fokus i forskningsprojektet. Nærmere bestemt fik informanterne frihed til at dyrke og betone de fortællinger, personer, steder og episoder, der stod centralt for dem hver især (Kvale \& Brinkmann, 2015, s. 185-189). For nogle af informanterne blev en tematik omkring målgruppen eksempelvis fyldig, mens andre var optaget af samarbejde med skole, kommune, kulturliv og foreninger.

Analysetilgangen i forskningsprojektet er abduktiv. I vores abduktive analyse veksler vi mellem begrebsudvikling med afsæt i teori på den ene side og empiriforankrede fortolkninger på den anden side - en dialog mellem teori og empiri (Järvinen \& Nanna, 2017). Eksempelvis er der i kraft af interviewguiden sat en ramme ved hjælp af tematikker baseret på eksisterende forskning på klubområdet. Denne ramme udstikker en retning for interviewene. Rammen forbliver dog meget løs, idet vi er optagede af informanternes egne betragtninger, fortællinger og italesættelser omkring deres professionsidentitet.

Efter gennemførsel af interviewene foretog vi en række gennemlæsninger af det samlede skriftlige materiale for at skabe overblik. I gennemlæsningsfasen farvekodede vi med henblik på at identificere forskellige narrativer på tværs af data. På trods af forskelle klubberne imellem, formulerede vi tre tværgående, relativt markante narrativer ud fra empirien: Pædagogen som demokratisk medborgerskaber, frihedens klubpædagog og pædagogen som sælger. Narrativerne har efterfølgende i analysen gjort det muligt at fremanalysere tre nøglefortællinger: nøglefortællingen om demokrati, nøglefortællingen om frihed og nøglefortællin-

1 Eksempler på spørgsmålsforslag i interviewguiden under tematikken "relationen til og arbejdet med målgruppen": "Kan du ikke prøve at fortælle mig om en situation, du har stået i sammen med de unge, der gjorde indtryk på dig, eller som du særligt husker?" 
gen om markedsgørelse. De tre nøglefortællinger leder frem til en udforskning af klubpædagogisk professionsidentitet i større perspektiv - som et fænomen, der ikke blot kan fremanalyseres og undersøges individuelt, men virker, opstår og etableres socialt og relationelt, indlejret i historie, kultur og faglighed.

\section{Klubpcedagogen som demokratisk medborgerskaber: en nøglefortalling om demokrati}

Dette narrativ konstrueres blandt andet ved analyse af informanternes sprogbrug. Samtlige informanter anvender udtryk som "demokrati", "demokratiske processer" og "demokratisk medborgerskab". Informanterne fremhæver gennemgående demokrati som grundværdi. En af lederne fra kommune a svarer, da han bliver spurgt til det centrale i klubbernes arbejde og klubpædagogens faglighed, at fundamentet i alt klubarbejde er "[...] den her demokratitanke - klubbernes ophav og dna.” På lignende vis kommer en af klubpædagogerne med følgende budskab:

"[...] det [demokrati] skal vi jo prcesentere dem for hele tiden. Det med at du har en stemme, du har ret til at sige noget, til at ytre dig [...] det skal de vide og det skal de loere" (kommune c)

Informanterne fortæller, at de anser det for deres opgave at lære målgruppen at indgå i et demokratisk samfund og blive demokratiske medborgere. Ifølge Jens Ulrich, ekstern lektor på VIA University College, indebærer et demokratisk medborgerskab en række pligter for det enkelte individ (2008). Ikke mindst er det centralt for klubpædagogerne, at målgruppen føler sig forpligtet på at opbygge fællesskaber med plads til alle: "Klubben er for alle. Vi ekskluderer ikke nogen - fordi hvis vi gør det, hvordan skal de lære at være en del af et samfund?" (klubpædagog, kommune b). Det handler, som en af klubpædagogerne udtrykker det, om at danne fællesskaber, hvor de unge kan lære "at sætte sig i de andres sted. Vi tilbyder dem muligheder for at møde og anerkende forskellige kulturer for derved at synliggøre forskellighed som en styrke" (kommune b).

Samtidig med at betone målgruppens pligt til at bidrage til inkluderende fællesskaber vægter alle informanterne børnenes og de unges ret til at være del af fællesskaberne. Arbejdet med målgruppens ret til at være deltagere i klubbens forskellige fællesskaber indebærer et særligt blik for børn og unge i udsatte positioner og en opmærksomhed i forhold til, at fællesskaberne skal byde dem velkomne som værdifulde, aktive deltagere. Denne del af narrativet kan analytisk sættes i forbindelse med socialpædagogikkens opdrag om (forebyggende) at tilbyde unge i udsatte positioner en meningsfuld fritid og meningsfulde fællesskaber (Larsen, 2015; Ankerstjerne, 2010, s. 50-52). Ud fra informanternes fortællinger bliver tillid, tryghed og relationsskabelse elementer i sikringen af målgruppens ret til at være værdifulde, aktive deltagere i fællesskaberne. For at arbejde med målgruppens ret til deltagelse er informanterne selv aktive deltagere i fællesskaberne, hvor de eksempelvis investerer en stor del af arbejdstiden i at tage lange, person- 
lige snakke med de enkelte børn og unge, hvor børnene og de unge bliver set og hørt, ikke kun af den enkelte pædagog, men også af kammeraterne. Interviewene vidner om lange samtaler i sofaen, hvor der tales om alt lige fra lektier og forældre til sex, venskaber og ondt i livet.

I forhold til rettighederne i demokratisk medborgerskab betoner informanterne i høj grad med- og selvbestemmelse: "Vi ønsker at lave et tilbud med medbestemmelse og selvbestemmelse. Du er nødt til at involvere de unge i beslutninger. Selvfølgelig skal de spørges: 'Hvad tænker du?'” (leder, kommune b). Et demokratisk medborgerskab indebærer ifølge Ulrich netop en række civile, sociale og politiske rettigheder (2008). At børnene og de unge i hverdagen har store muligheder for selv- og medbestemmelse kommer blandt andet til udtryk i informanternes fortællinger fra praksis. Som i dette eksempel, hvor en ansat fortæller om, hvordan 6. klasserne i klubben ønskede deres eget rum: "De har spurgt, om de måtte få et rum. Det har vi sagt ja til; og de har været medbestemmende og selv lavet rummet" (kommune a). Et andet eksempel, hvor pædagogerne giver børnene rettigheder til selv- og medbestemmelse, er klubbernes etablering af børne- og ungeråd. Trine Ankerstjerne fremhæver i sin analyse af fritidspædagogikken selvforvaltning og selvbestemmelse som centrale værdier i feltet, hvor pædagogikken baserer sig på "en stolt tradition for at lade børnene komme til orde" (2010, s. 59).

I praksis arbejder pædagogerne desuden med demokrati ved at hjælpe børnene og de unge med at blive politiske subjekter i et demokratisk samfund. Ikke mindst den politiske dialog om problemstillinger i samfundet generelt bydes velkommen: "Politisk snak, det er vi ikke blege for at tage" (klubpædagog, kommune c). I praksis betyder det, at informanterne inviterer til dialog og diskussion. Interviewene indeholder mange beretninger om politiske diskussioner i sofaen, over madlavningen eller foran tv'et, hvor klubpædagogerne bevidst tænder for nyhederne eller debatprogrammer for at invitere til dialog.

Narrativet om den demokratiske pædagog gør det muligt at fremanalysere en motiverende nøglefortælling om demokrati i klubpædagogernes professionsidentitet. Vores tolkning er, at nøglefortællingen trækker tråde tilbage til reformpædagogikken og den kritisk frigørende pædagogik, som netop (klub)fritidspædagogikken har været inspireret kraftigt af i det 20. århundrede (Ankerstjerne, 2010). Inden for den europæiske reformpædagogik var pædagogikkens funktion at bidrage til lighed, frihed, styrkelse af demokratiet og dannelse af demokratiske medborgere, blandt andet ved at inddrage børn og unge i beslutninger (Kampmann, 2017a). Tilsvarende står demokratiet centralt i den kritisk frigørende pædagogik, der også har sat sit tydelige præg på fritidspædagogikken: "Den kritisk-frigørende pædagogik har virket som særlig inspirationskilde [...] med et demokratisk sigte" (Ankerstjerne, 2010, s. 67) (Kampmann, 2017b). Nøglefortællingen kan fremanalyseres ud fra informanternes narrative viden og fortællinger om selvbestemmelse, medbestemmelse, fællesskaber og (politisk) dialog. På mange måder fremstår nøglefortællingen som en grundmetafor og norm i klubfeltet, der i den daglige praksis legemliggøres og konstrueres gennem det kulturelt 
overleverede narrativ pædagogen som demokratisk medborgerskaber, bestående af en række stories to live by. Wackerhausen beskriver, hvordan en professions veletablerede fagudøvere har "[...] et omfattende fællesindhold i deres respektive professionsidentiteter", hvor professionsidentiteten i høj grad sammensættes "ved at gå i de veletablerede og anerkendte fagudøveres veltrådte stier" (Wackerhausen, 2004, s. 17 og 22).

\section{Frihedens klubpcedagog: en nøglefortcelling om frihed}

Det næste narrativ har overskriften "frihedens klubpædagog". I interviewene taler mange af informanterne om den "frie tid", om "lyst" og om at give målgruppen "plads" og "frihed". Informanternes argumentation baserer sig umiddelbart ofte på generelle iagttagelser omkring målgruppens liv. De fortæller om pressede børn og unge i et samfund, der konstant måler dem. En leder fortæller, hvordan de "unge mistrives og føler sig pressede i dagligdagen, og at muligheden for at være ung, med alt hvad det indebærer, drukner i alt for meget måling og styring" (kommune b). Som reaktion vægter informanterne, at de i praksis skal initiere et frirum og værne om målgruppens autonomi i deres fritid. Som en af klubpædagogerne siger, skaber de rum for, at målgruppen kan "puste ud og møde nogen, der ikke nødvendigvis har de store krav til dig [...] hvor de bare lige kan sidde og koble helt af, stå helt af ræset” (kommune a). Klubpædagogernes dyrkelse af klubben som frirum præger umiddelbart deres praksis, ikke mindst aktiviteterne. Pædagogikken synes børne- og ungecentreret, baseret på målgruppens perspektiver. Aktiviteterne formes ofte først undervejs i mødet med målgruppen. Det er deres fritid og interesser, der styrer. Som i eksemplet her:

"Der var nogle børn, der kom hen til mig og sagde: 'vi vil spille rollespil!' Så sagde jeg: 'hvad er det? Nå, jamen, så lad os kaste os over det!' Og så gik jeg ind $i$ det sammen med de her børn, og vi undersøgte, hvad det var for noget." (pcedagog, kommune a)

Narrativet kan delvist begribes i opposition til skolesystemet. I et af interviewene taler en leder om, hvordan presset på målgruppen især kommer fra skolen og italesætter derefter klubpædagogernes rolle som "noget andet" end skolen (kommune a). Hun fortæller, at klubpædagogerne gør " [...] meget ud af at fortælle de unge, vi gerne vil hjælpe dem med at blive til nogen, i stedet for at blive til noget" og argumenterer for, at "folkeskolen har fokus på at blive til noget, og vi har fokus på at blive til nogen" (kommune a). En anden informant, der også karakteriserer målgruppen som presset, fortæller, hvordan denne iagttagelse præger klubaktiviteterne:

"Og det der med at de fär lov til at sidde og prøve ting af og fejle og lave det om. Og det er gratis det hele. På den måde, der er ikke sådan en afregning ved kasse et, som der er $i$ skolen, hvor der er mål og vejning” (kommune b). 
Også dette narrativ kan anvendes til at identificere en nøglefortælling i klubpædagogisk professionsidentitet med rødder i reformpædagogik og kritisk frigørende pædagogik. Ankerstjerne skriver i sin analyse af fritidspædagogikkens historiske udvikling, hvordan værdier som frihed, frirum og fritid i høj grad gennem det 20. århundrede har formet området (2010). Vi tolker informanternes udsagn om en presset målgruppe som bidrag til en professionsidentitet, der på en række områder står i opposition til mere overordnede samfundsmæssige vilkår og ikke mindst til skolen. På den måde opbygges nøglefortællingen delvist gennem grænsedragning og modidentifikation (Gilliam, 2017). Pædagogerne på det samlede fritidspædagogiske område (både klub og SFO) anser sig selv som forsvarere i forhold til børns rettigheder (Ankerstjerne, 2010, s. 64-67). Disse karakteristika kan især forbindes til kritisk frigørende pædagogik, hvor klubpædagogikken værner om målgruppens fritid og frihed (Ankerstjerne, 2010). Pædagogikken, de pædagogiske aktiviteter og de pædagogiske rum, bliver i høj grad, for at værne om fritid og frihed, baseret på målgruppens egne perspektiver og interesser.

\section{Klubpadagogen som scelger: en nøglefortcelling om markedsgørelse}

Det tredje narrativ konstruerer vi blandt andet ud fra en iagttagelse af informanternes hyppige brug af forretningsord og -vendinger som "kunder i butikken", "vi skal sælge os selv", "business", "udsolgt", "køb", "salg" og "marked". En af lederne fortæller, at klubbens overlevelse og økonomi for ham at se adskiller sig fra andre pædagogiske institutioners vilkår. Han oplever strammere vilkår efter skolereformen, hvor klubberne fik reduceret åbningstiden. Han fortæller, hvordan flere klubber er lukkede og understreger: "Vi er nødt til hele tiden at være på forkant. Der er nogle andre kræfter, markedskræfter, på klubområdet end på SFO- og skoleområdet" (kommune a). Som vi illustrerer i nedenstående analyse, synes informanterne at være splittede i deres forhold til og syn på sælgerrollen. På den ene side oplever de det som pres og lukningstrussel, at de konstant skal sælge sig selv, på den anden side beskriver flere af dem, hvordan netop det at skulle sælge sig selv kan motivere til opfindsomhed, kreativitet, udvikling, faglig bevidsthed og synliggørelse.

En af klubbernes primære kunder er naturligvis børnene og de unge. En kundegruppe hvis præferencer og interesser er skiftende og forskelligartede og som dagligt modtager en række andre konkurrerende fritidstilbud: "I deres frie tid, der skal de vælge: 'vil jeg gå til spring... e-sport eller i klub?' Hvis vi ikke er dygtige nok, så bliver vi da valgt fra" (leder, kommune b). Udsagnet vidner om et frit forbrugervalg, hvor klubbernes overlevelse afhænger af salgsbare produkter. I EVA rapporten "Børn og unges brug af klubtilbud" indkredses det, hvordan en væsentlig faktor i forhold til, om børn og unge vælger klublivet til, er udbuddet af aktiviteter, og om målgruppen finder disse aktiviteter "spændende" (2018, s. 8). For at kunne tilbyde et attraktivt produkt er det nødvendigt hele tiden at følge 
med i de nye trends og interessefelter, der opstår i børneungefeltet blandt andet ved at aflæse eller, som en af pædagogerne udtrykker det, at "bruge" målgruppen, fordi den, ifølge ham, "kan hjælpe os med at være på" (kommune b).

En anden primær kundegruppe er kommune og forvaltning, hvis behov og ønsker også skal imødekommes. I alle tre kommuner fortæller informanterne om kontrakter, der kontinuerligt skal genforhandles med kommune, forvaltning og skoler. Informanternes salg ud af huset har blandt andet medført skærpede krav om systematik, evaluering, skriftlighed og dokumentation: "Det er et voldsomt fokus og vi skal registrere og vi skal gøre ved. Vi skal sikre, at de der kære politikere ved, at vi faktisk har unge her i klubben" (leder, kommune b). Ifølge en af lederne i kommune a påvirker disse krav ansættelsen af nye klubpædagoger: "Jeg kan ikke bruge en klubpædagog, der ikke kan skrive [...] vi skal dokumentere, vi skal lave handleplaner, vi skal lave al mulig opfølgning på alle mulige ting” (kommune a).

I kommune a og c indebærer det at samarbejde med kommune og forvaltning et tæt parløb med skolen. Klubpædagoger købes blandt andet ind til individuelle trivselsforløb, understøttende undervisning eller timer med en lærer i skolen. I kommune a har det samlede klubområde desuden et katalog til åben skole, hvor skolerne kan købe eksempelvis dramaforløb eller teambuildingsforløb. I interviewene beretter nogle af informanterne om de muligheder, det øgede samarbejde med skolen har medført: muligheden for at følge børnene og de unge på tværs af skole og fritid, muligheden for at styrke forældresamarbejdet, muligheden for at bruge klubfagligheden i skolen. Der er dog også en række fortællinger fra informanterne, der vidner om udfordringer, hvad angår samarbejdet med skolen og skolens brug af klubpædagogerne. I interviewene er der fortællinger om, hvordan de, med deres egne ord, bliver brugt som "lærervikarer" eller "radiatorpædagoger" og ikke oplever at få deres klubpædagogiske professionsidentitet i spil (klubpædagoger, kommune a og c). Dertil kommer udfordringen i at blive set, husket og anerkendt som samarbejdspartner i arbejdet med børn i udsatte positioner, matrikelsammenlægning af klub og skole med videre:

"Det har voeret rigtig meget op ad bakke at blive set som klub og blive anerkendt som klub [...] ved første udkast [plan om matrikelsammenloegning af skole og klub], der var klubben toenkt ind til, at vi kunne få to klasselokaler, som skulle voere klar til undervisning dagen efter. Så måtte vi jo så hive vores ting frem og tilbage [...]. Der havde man ikke lige toenkt at 'klub ok - hvad er det egentlig for noget?' [...] Så vi oplever rigtig meget, at der er folk, som sidder $i$ de her styregrupper, og som har magt og kan bestemme noget, faktisk ikke har den fjerneste anelse om, hvad klub er for noget - hvad der foregår her" (klubpcedagog, kommune a).

I kommune b fortæller informanterne ikke om skolesamarbejde som central del af en salgsstrategi. Men produktet skal stadig i lige så høj grad som i kommune a og c sælges kommunalt, hvis klubberne skal overleve. Som en af informanterne understreger, forudsætter klubbens overlevelse og legitimitet, at den "ikke lukker sig om sig selv" men fastholder samarbejdet ud af klubben (leder, kommune b). 
Det sker blandt andet gennem aktivt samarbejde med eksempelvis lokale spillesteder, museer og udviklingsprojekter i byrummet. Dertil kommer en række kommunalt formulerede, bundne opgaver eller "kommunale ordrer", som en af informanterne udtrykker det, eksempelvis etableringen af et ungeråd, som klubben pålægges at varetage med retningslinjer fra kommunen: "Jamen det er her på jeres [klub]område, det skal forankres, det er jer, der skal gøre det [...]. Og det er jer, der skal sørge for, at den når i mål” (klubpædagog, kommune b).

Umiddelbart fremskriver analyser foretaget af eksempelvis Ankerstjerne ikke en tydelig nøglefortælling om markedsgørelse (2010). Alligevel vil vi, med afsæt i narrativet om pædagogen som sælger, argumentere for, at der er en sådan nøglefortælling på spil i klubpædagogisk professionsidentitet. En nøglefortælling, hvor det ikke mindst handler om at tiltrække børnene og de unge som kunder. Dertil kommer, at klubberne i endnu højere grad end tidligere, som følge af blandt andet kommunalreform og skolereform, samtidig skal tiltrække og overbevise en anden primær kundegruppe, kommunen og forvaltningen. Järvinen og Mik Meyer beskriver i en analyse af velfærdsprofessionelle, hvordan kritik af velfærdsstaten, velfærdsprofessioners professionalitet, systematik og effektivitet generelt på feltet har medført stigende kontrol, målstyring og evaluering af blandt andet pædagogers arbejde (Järvinen \& Mik-Meyer, 2012, s. 15-27). En kontrol og evaluering, der kan genkendes i narrativet pædagogen som sælger. For at sælge produktet og legitimere sig, skal klubpædagogen kunne udtrykke sig skriftligt, dokumentere og evaluere i samarbejdet ud af klubben. Derudover kan såvel klubledernes som -pædagogernes fortællinger om et presset klubfelt, om nødvendigheden af samarbejde, om nødvendigheden af at overbevise samarbejdspartnere og politikere om klubbernes kvalitet og værdi og ikke mindst deres brug af forretningssprog fortolkes ved hjælp af Järvinens og Mik-Meyers analyse af de professionelle som en gruppe, der "[...] befinder sig på et marked af kontraktprægede relationer, konkurrence, cost-benefit analyser og antagelser om 'kundeefterspørgsel' " (Järvinen \& Mik-Meyer, 2012, s. 15). Nøglefortællingen om markedsgørelse trækker ikke tråde så langt tilbage i klubpædagogikkens historie og rødder som de to øvrige nøglefortællinger. Der er tale om en historisk nyere nøglefortælling, som efter vores mening kan forbindes til eller fortolkes i lyset af New Public Management-bølgen, der for alvor har sat dagsordenen inden for den offentlige og sociale sektor fra 00'erne og frem (Hjort, 2012; Kamp, Hohnen, Hvid og Scheller, 2013). Nøglefortællingen kan bruges som eksempel på den dynamik og foranderlighed (professions)identitet, ifølge Jenkins, er kendetegnet ved: "[...] identity can only be understood as process, as 'being' or 'becoming'. One's identity [...] is never a final or settled matter." (Jenkins, 2004, s. 5). Nærmere bestemt kan en øget markedsgørelse i samfundet generelt have tilført nye elementer, der i de senere år har påvirket klubpædagogisk professionsidentitet og praksis indefra. Wackerhausen fremhæver, hvordan eksterne (samfundsmæssige, politiske, strukturelle) forhold med tiden kan indoptages i den enkelte professionsudøver og påvirke professionsidentitet og praksis (Wackerhausen, 2004, s. 14-17). 


\section{Afrunding og diskussion}

Med afsæt i analysen af de tre nøglefortællinger kan vi identificere en overordnet fortælling om klubpædagogisk professionsidentitet mellem tradition og forandring, hvor klubpædagoger og -ledere navigerer og veksler mellem at vægte og praktisere demokrati, frihed og markedsgørelse. Vi tolker nøglefortællingerne om demokrati og frihed som tegn på tradition og klassiske fritidspædagogiske elementer og værdier i den klubpædagogiske professionsidentitet med tråde til reformpædagogik og kritisk frigørende pædagogik. Over for, og i samspil med disse to nøglefortællinger, står nøglefortællingen om markedsgørelse. Klubpædagogen skal sælge eller overbevise omverdenen, kunderne, om værdien og brugbarheden af klubbernes arbejde. I modsætning til de to andre nøglefortællinger, kan den historisk nyere nøglefortælling om markedsgørelse tolkes som tegn på forandring i den klubpædagogiske professionsidentitet.

Afslutningsvis vil vi diskutere, hvilke udfordringer og muligheder mødet mellem på den ene side nøglefortællingerne om demokrati og frihed og på den anden side nøglefortællingen om markedsgørelse kan betyde i forhold til kommuners og forvaltningers anerkendelse af klubpædagogisk professionsidentitet.

En mulig tolkning er, at nøglefortællingen om markedsgørelse og klubområdets tilsyneladende opsathed på at levere varen for at overleve på sigt kan udfordre, fortrænge eller udhule de to klassiske pædagogiske nøglefortællinger om demokrati og frihed. I yderste konsekvens kan dette føre til, at nøglefortællingen om markedsgørelse kommer til at dominere klubområdet. En dominans, der givetvis vil kunne dekonstruere klubpædagogisk professionsidentitet. Ud fra vores empiriske analyse er der ingen tvivl om, at markedsgørelsen presser klubområdet og tvinger til mere eller mindre konstant udvikling, hvis området skal bestå. Imidlertid finder vi en tolkning alene i den retning for reduktionistisk. Vi vil i det følgende, med udgangspunkt i Whites teori om identitetsfordring, fremsætte alternativ tolkning og argumentere for, at markedsgørelsen muligvis lige så vel kan indeholde potentialer og muligheder, hvis klubpædagogisk professionsidentitet skal anerkendes af omverdenen og demokrati og frihed forsat skal stå centralt i professionsidentiteten.

Vi tolker de tre nøglefortællingers dominans på tværs af materialet som tegn på, at klubpædagogerne internt har konstrueret dele af det, der, med Michael Whites teoriapparat, kan betragtes som en selvfortælling og intern identitetskonklusion (2008). Den interne identitetskonklusion er, som nævnt imidlertid kun første led i en treleddet positioneringsproces og identitetsfordring - det at få anerkendt (professions)identiteten (2008):

1. Konstruktion af intern selvfortælling/identitetskonklusion på klubområdet

2. Positionering over for omverdenen ud fra intern selvfortælling/identitetskonklusion på klubområdet

3. Omverdenens anerkendelse/underkendelse, accept/afvisning af den interne selvfortælling/identitetskonklusionen på klubområdet 
Spørgsmålet er, hvor langt klubområdet er nået i trin to og tre af positioneringsprocessen? Har klubpædagogerne formået at eksplicitere deres professionskonklusion over for omverdenen, i dette tilfælde kommune og forvaltning? Hvis det er tilfældet, bliver det næste spørgsmål omkring identitetsfordringer, hvordan kommune og forvaltning tager imod klubbernes identitetskonklusion? Anerkender eller underkender de klubpædagogernes professionsidentitet? Kan de se relevansen? Efterspørger de demokrati og frihed, eller er de optaget af noget helt andet? Vores empiriske materiale giver os ikke mulighed for at belyse og diskutere disse spørgsmål. I stedet inddrager vi i vores afsluttende diskussion den hollandske uddannelsesforsker Gert Biestas begreber socialisering, subjektifikation og kvalifikation for at diskutere spørgsmålene (2015). Socialisering, subjektifikation og kvalifikation er, ifølge Biesta, tre helt centrale uddannelsesdomæner. Vendes blikket i første omgang mod de to traditionelle nøglefortællinger om demokrati og frihed, vil vi argumentere for, at disse kan relateres til Biestas indkredsning af socialisering og subjektifikation (2015). ${ }^{2}$ Socialiseringsdomænet omhandler de processer, hvor målgruppen gennem diverse aktiviteter socialiseres og socialiserer sig selv og hinanden ind i eksisterende praksisser, kulturer, traditioner, mens subjektifikationsdomænet skriver sig ind i den subjektive dannelse (Biesta, 2015, s. 107-110). Vi vil videre, med afsæt i Biestas analyse, argumentere for, at kommunerens og forvaltningernes fokus i forhold til børn og unge i dag i udgangspunktet oftere er på et kvalifikationsdomæne, frem for på socialiserings- og subjektiveringsdomænerne, som klubberne umiddelbart relaterer til. I kvalifikationsdomænet fokuseres der på faglige resultater, synlig læring og kompetenceudvikling. Biesta argumenterer for, at alle tre domæner i udgangspunktet altid bør være til stede i al uddannelse. Imidlertid dominerer kvalifikationsdomænet, ifølge ham, og det presser de to øvrige domæner (Biesta, 2009). Hvis sidstnævnte pointe forfølges, kan et dominerende fokus på kvalifikation fra kommunernes og forvaltningernes side vanskeliggøre anerkendelsen af den del af klubpædagogernes professionskonklusion, der baserer sig på nøglefortællingerne om demokrati og frihed med vægtning af socialiserings- og subjektiveringsdomænerne. Hvordan sælge demokrati og frihed, hvis kommuner og forvaltninger er optaget af kvalifikation, kompetenceudvikling og synlig, målbar læring?

På den anden side kan der ud fra Biestas analyse og kritik af kvalifikationsdomænets dominans i det nuværende samfund argumenteres for, at klubpædagogerne måske netop kan spille en væsentlig og legitim rolle i samfundet i kraft af nøglefortællingerne om demokrati og frihed. De to nøglefortællinger kan fungere som modspil til kvalifikationsdomænets dominans og bidrage til bedre balance mellem de tre domæner. Her når vi til den førnævnte argumentation om mulige potentialer i nøglefortællingen om markedsgørelse. Givetvis ligger der et udviklingspotentiale i kraft af sælgeren i forhold til at fastholde og eksplicitere nøglefor-

2 Biestas teori handler om (ud)dannelse og undervisning i bredere forstand "som den udfolder sig i skolen eller andre steder" (Biesta, 2015, s. 107). Efter vores mening kan klubområdet betragtes som del af dette (ud)dannelsessystem, nærmere bestemt en mere perifer og uformel del af det danske uddannelsessystem. 
tællingerne om demokrati og frihed. Interviewene fra de tre kommuner vidner om, hvordan klubberne generelt arbejder på at synliggøre og sælge deres produkter til skole, kommune og forvaltning, og at de i en række tilfælde lykkes på kreativ vis med at få solgt klubpædagogik gennem idékatalog til åben skole, mentoråbninger, samarbejder med museer, lokale spillesteder med videre. Kunne der gennem målrettet og bevidst markedsførelse og strategi tages faglige klubpædagogiske livtag med kvalifikationsdomænets dominans? Kunne klubpædagogerne og -ledere som sælgere, mere eksplicit end hidtil og blandt andet med afsæt i viden om målgruppen og målgruppens behov, insistere på nødvendigheden af at fastholde og endog styrke fokus på socialisering og subjektivering ved at dyrke demokrati og frihed?

Udover at bidrage med viden om klubpædagogisk professionsidentitet, til gavn for både pædagoguddannelse og pædagogisk praksis, har vores formål med artiklen været, som diskussionen oven for illustrerer, at invitere til videre diskussion og debat om klubberne. Klubområdet er til stadighed under forandring. Forandringer, der for os at se kalder på yderligere eksplicitering, mere forskning og flere diskussioner omkring klubbernes samfundsmæssig værdi og formål: hvad er det, klubområdet gør, vil og skal med børnene, de unge og pædagogikken - både nu og i fremtiden?

\section{Litteratur}

Ankerstjerne, T. (2010). Fritidspædagogik - før, nu og lige om lidt! I T. Ankerstjerne, SFO- og fritidspcedagogik - før, nu og i fremtiden (s. 49-74). København: Dafolo.

Bayer, S., \& Jørgensen, M.D. (2016). Klubberne i Aarhus i et vadested. Aarhus: BUPL.

Biesta, G. (2009). Good education in an age of measurement: on the need to reconnect with the question of purpose in education. Educ Asse Eval Acc, s. 33-46.

Biesta, G. (2015). Hvad skal vi stille op med børnene? Om uddannelse, modstand og dialogen mellem barn og verden. I J. Klitmøller, \& D. Sommer, Loering, dannelse og udvikling (s. 105123). København: Hans Reitzels.

Evalueringsinstitut, D. (2018). Børns og unges brug af fritids- og klubtilbud - Overblik og fakta. København: EVA. Hentet fra Danmarks Evalueringsinstitut. (2018). Børns og unges brug af fritids- og klubtilbud - Ohttps://www.eva.dk/sites/eva/files/2018-01/EVA\%20Fritid_og_klub_ pixi_WEB_NY_0.pdf

Gilliam, L. (2017). Identitet - kategoriseringer og sociale dynamikker. I E. Gulløv, G.B. Nielsen, \& I.W. Winther, Poedagogisk antropologi (s. 121-141). København: Hans Reitzel.

Gravesen, D.T., \& Ringskou, L. (December 2019). Hvad ved vi egentlig om skole- og fritidspædagoger. Social Kritik, s. 76-86.

Gravesen, D.T., \& Ringskou, L. (Marts 2020). Med viden skal skole- og fritidspædagogik bygges En kortlægning og kritisk analyse af forskningsbaseret litteratur på feltet for skole- og fritidspædagogik i Danmark. Forskning i Pcedagogers Profession og Uddannelse.

Hjort, K. (2012). Det affektive arbejde. København: Samfundslitteratur.

Jenkins, R. (2004). Social identity. London: Routledge.

Järvinen, M., \& Mik-Meyer, N. (2012). At skabe en professionel. I M. Järvinen, \& N. Mik-Meyer, At skabe en professionel. Ansvar og autonomi i velfordsstaten (s. 13-29). København: Hans Reitzel.

Kamp, A., Hohnen, P., Hvid, P., \& Scheller, V.K. (2013). New Public Management - konsekvenser for arbejdsmiljø og produktivitet. Skriftserie for CAF, CEnter for Arbejdslivsforskning. 
Kampmann, J. (2017a). Progressiv pædagogik og reformpædagogik. I P. Ø. Andersen, \& T. Ellegaard, Klassisk og moderne paedagogisk teori (s. 871-881). København: Hans Reitzel.

Kampmann, J. (2017b). Paulo Freire. I P. Ø. Andersen, \& T. Ellegaard, Klassisk og moderne pcedagogisk teori (s. 772-777). København: Hans Reitzel.

Kvale, S., \& Brinkmann, S. (2015). Interview. Det kvalitative interview som forskningsmetode. København: Hans Reitzel.

Larsen (red.), J. (2018). Er du på tvœers? Om at lede og kryser grcenser i nye pæedagogiske landskaber. Odense: Ungdomsringen.

Larsen, J. (2015). Fritid - den nye elev i klassen. Strategisk pcedagogisk ledelse. Odense: Ungdomsringen.

Mikkelsen, J.H., Hansen, M.A., \& Munkholm, T. (2017). Love og konventioner på skole- og fritidsområdet. I D.T. Gravesen, Pcedagogik i skole og fritid (s. 222-244). København: Hans Reitzel.

Munksgaard, K.F., Schmidt, C.H., \& Skovgaard, T. (2019). Professionsidentitet i bevægelse. Forskning i Poedagogers Profession og Uddannelse (FPPU), volume 3(1), s. 68-86. Hentet fra https:// tidsskrift.dk/FPPU/article/view/113973/162555

Togsverd, L., Rothuizen, J.J., Jørgensen, H.H., \& Weise, S. (2017). Om modstand, frihed og myndigblivelse i daginstitutionen. Forskning $i$ padagogers profession og uddannelse, volume 1(2), s. $70-84$.

Ulrich, J. (2008). Demokratisk medborgerskab - skal vi være ens for at blive enige? I A.V. Oettingen, L. Komischke-Konnerup, \& N.B. Hansen, Medborgerskab - en udfordring til efterskolen (s. 77-87). København: Unge Pædagoger.

Wackerhausen, S. (2004). Professionsidentitet, sædvane og akademiske dyder. I N.B. Hansen, \& J. Gleerup, Videnteori, professionsuddannelse og professionsforskning. Syddansk Universitetsforlag.

White, M. (2008). Kort over narrative landskaber. København: Hans Reitzel. 